DOI: https://doi.org/10.24127/ajpm.v10i4.4308

\title{
PENGEMBANGAN BAHAN AJAR KALKULUS INTEGRAL BERBASIS PENDEKATAN COMPUTATIONAL THINKING
}

\author{
Fariz Setyawan $^{1 *}$, Dwi Astuti ${ }^{2}$ \\ ${ }^{1,2}$ Pendidikan Matematika, Universitas Ahmad Dahlan, Yogyakarta, Indonesia \\ *Corresponding author. Dusun Klenggotan, Piyungan, Bantul DI Yogyakarta, Indonesia \\ E-mail: fariz.setyawan@pmat.uad.ac.id ${ }^{\left.l^{*}\right)}$ \\ dwi.astuti@pmat.uad.ac.id ${ }^{2}$
}

Received 10 October 2021; Received in revised form 16 November 2021; Accepted 17 December 2021

\begin{abstract}
Abstrak
Dampak pendemi memaksa mahasiswa lebih menyukai pembelajaran dengan menggunakan e-learning ataupun WhatsApp dibandingkan dengan platform lain. Berkaitan dengan hal tersebut maka perlu dikembangkan bahan ajar yang terintegrasi dengan teknologi terkini yang bersifat adaptif dan dapat diakses kapanpun dan dimanapun oleh mahasiswa. Tujuan penelitian ini adalah mengembangkan bahan ajar mata kuliah Kalkulus Integral berbasis pendekatan Computational Thinking (CT) yang valid dan praktis. Penelitian ini merupakan penelitian pengembangan dengan model pengembangan Plomp yang meliputi tahap preliminary research, prototyping, dan assesment. Instrumen yang digunakan meliputi angket validitas ahli, angket respon mahasiswa terhadap e-modul, dan angket respon mahasiswa terhadap pembelajaran. Teknik analisis data menggunakan sistematik refleksi dan dokumentasi untuk menghasilkan teori atau prinsip desain secara ilmiah. Bedasarkan hasil penelitian diperoleh bahwa bahan ajar sangat valid $(\mathrm{Sr}=4,76)$ dan praktis $(\mathrm{Pr}=3,79)$. Selain itu, melalui refleksi pembelajaran diperoleh sebanyak 73,3\% mahasiswa memahami konsep yang diberikan, 46,7\% mahasiswa mengaitkan pengetahuan mahasiswa sebelumnya, $40 \%$ mahasiswa setuju dosen melakukan pembimbingan saat mahasiswa menyelesaikan masalah, 53,3\% mahasiswa mendapatkan kesempatan untuk berdiskusi dan menyampaikan pendapat, dan $40 \%$ mahasiswa setuju bahwa dosen memberikan kesempatan untuk mengevaluasi diri melalui tugas yang diberikan di e-learning. Saran untuk penelitian berikutnya adalah dapat melanjutkan penelitian eksperimen untuk mengukur pengaruh penggunaan bahan ajar yang telah dikembangkan.
\end{abstract}

Kata kunci: bahan ajar; kalkulus integral; praktis; valid

\begin{abstract}
The impact of the pandemic has forced students to prefer learning by using e-learning or WhatsApp compared to other platforms. This encourages researchers to provide teaching materials that are integrated with the latest technology that is adaptive and can be accessed anytime and anywhere by students. The purpose of this research is to develop a valid and practical teaching materials in Integral Calculus course based on Computational Thinking (CT) approach. The development model used is a research design model of the type of development studies by Plomp such as preliminary research, prototyping, and assesments. The instruments of the research are questionnaire of expert validity, students' response of e-modul and learning process. The data analyzed by systematic reflection and documentation to produce scientific theories or principle. Based on the results of the study, it was found that the teaching material is compelling $(\mathrm{Sr}=4.76)$ and practical $(\mathrm{Pr}=3.79)$. Meanwhile, as measured through the reflection of CT-based learning was obtained by as many as $73.3 \%$ of students understood the concepts given, $46.7 \%$ of students linked previous student knowledge, $40 \%$ of students agree that lecturers provide guidance when students solve problems, $53.3 \%$ of students get the opportunity to discuss and convey their thoughts during lectures, and $40 \%$ of students agree that lecturers provide opportunities to evaluate themselves through assignments given in e-learning. Suggestions for future research are to continue experimental research in measuring the effect of using developed teaching materials.
\end{abstract}

Keywords: integral calculus; practically; teaching materials, valid 


\section{PENDAHULUAN}

Dosen sebagai fasilitator dalam pembelajaran memiliki peran dalam mengembangkan kecakapan mahasiswa terutama dalam mengembangkan kompetensinya seperti kemampuan pemecahan masalah termasuk abstraksi, dekomposisi, evaluasi, pola, recognition, logika, dan desain algoritma. Di era industry 4.0, Computational Thinking menjadi keterampilan dasar yang harus dimiliki oleh mahasiswa seperti halnya kemampuan membaca, menulis, dan berhitung (J. M. Wing, 2014; Tabesh, 2017). Computational Thinking (CT) meliputi kemampuan berpikir spesifik, pemikiran algoritmik, penalaran, pola, pemikiran prosedural dan pemikiran rekursif, kemampuan pemecahan masalah termasuk abstraksi, dekomposisi, evaluasi, pola, recognition, logika, dan desain algoritma (Wing, 2011; Grover \& Pea, 2018). Dosen dituntut untuk kreatif dalam mengembangkan desain dan bahan ajar yang menarik minat dan motivasi mahasiswa dalam belajar.

Pengembangan bahan ajar yang dilakukan oleh dosen merupakan salah satu upaya agar mahasiswa dapat mengembangkan kemampuan computational thinking seperti kemapuan dalam mengabstraksi, mendekomposisi, mengevaluasi, mengembangkan pola, logika, dan desain algoritma dari materi yang dipelajarinya. Dosen tidak hanya memberikan materi dan penugasan kepada mahasiswa, tetapi dosen lebih berperan memberikan scafollding selama proses pembelajaran berlangsung.

Salah satu media yang dapat digunakan untuk mengakomodasi kebutuhan tersebut adalah dengan adanya optimalisasi penggunaaan
Learning Management System (LMS) berupa e-learning sehingga dapat diakses kapanpun dan dimanapun oleh mahasiswa. Penelitian mengenai keefektifan penggunaan platform daring telah banyak diungkap oleh beberapa peneliti (Jacinto \& Carreira, 2021; Pischetola, de Miranda, \& Albuquerque, 2021; Setyawan, Prasetyo, \& Nurnugroho, 2020). Oleh karena itu pengembangan bahan ajar sebaiknya tidak hanya mengenai perubahan dari bentuk fisik menjadi bentuk digital saja, namun perubahannya mengarah pada penyesuaian pola interaktivitas yang ditawarkan pada bahan ajar yang dikembangkan (Pischetola et al., 2021).

Berdasarkan survei kepada 19 (sembilan belas) mahasiswa di semester II tahun ajaran 2020/2021, diperoleh sebanyak 13 (tiga belas) mahasiswa lebih menyukai pembelajaran dengan menggunakan e-learning ataupun whatsapp dibandingkan dengan platform lain (lihat Gambar 1). Berdasarkan hal tersebut maka perlu disediakan bahan ajar yang terintegrasi dengan teknologi terkini yang bersifat adaptif dan dapat diakses kapanpun dan dimanapun oleh mahasiswa. Penggunaan teknologi membantu dosen dalam mengembangkan beberapa kompetensi mahasiswa dan aspek-aspek pembelajaran di kelas (Domingo \& Garganté, 2016).

Selain itu, bahan ajar yang dikembangkan diharapkan mampu mengakomodasi ide-ide abstrak yang terjadi selama proses perkuliahan melalui pendekatan pembelajaran yang dapat relevan dan menstimulasi kemampuan pemecahan masalah mahasiswa (Son, Darhim, \& Fatimah, 2020). Melalui aktivitas yang melibatkan kemampuan pemecahan masalah tersebut, dosen dapat memfasilitasi mahasiswa dalam 
mengembangkan kompetensi mereka. Salah satu pendekatan pembelajaran yang dapat mengakomodasi ide-ide abstrak tersebut adalah pendekatan Computational Thinking (CT). Pendekatan CT memiliki ciri dosen sebagai fasilitator mendekomposisi ideide abstrak suatu konsep (Angeli \& Giannakos, 2020; Yadav, Zhou, Mayfield, Hambrusch, \& Korb, 2011). Adapun proses dalam model Computational Thinking terdiri dari 5 tahap, yaitu: melibatkan pemecahan masalah besar menjadi yang lebih kecil (decomposition), mengenali bagaimana pemecahan masalah ini berhubungan dengan masalah yang telah diselesaikan di masa lalu (pattern recognition), mengesampingkan detail yang tidak penting (abstraction), mengidentifikasi dan mengembangkan langkah-langkah yang akan diperlukan untuk mencapai solusi (algorithms), memperbaiki langkah-langkah pemecahan masalah ini (debugging) (Angeli \& Giannakos, 2020). Melalui aktivitas dekomposisi tersebut, dosen diharapkan dapat meningkatkan kemampuan pemecahan masalah mahasiswa terutama pada mata kuliah rumpun analisis yaitu kalkulus integral.

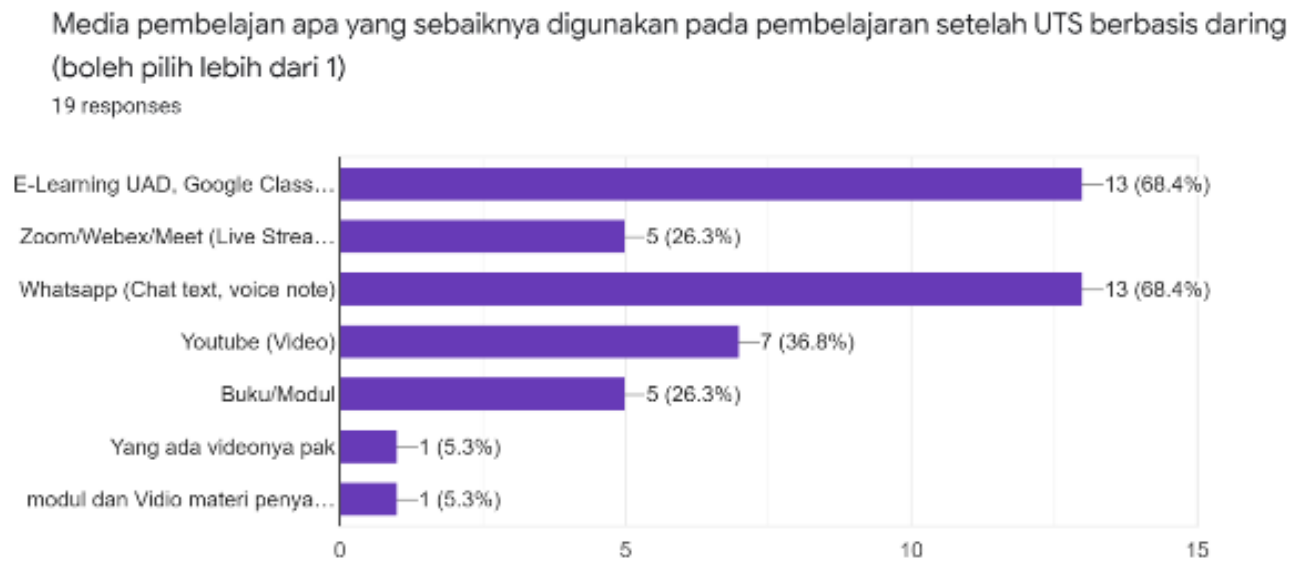

Gambar 1. Data Preferensi Media Ajar Mahasiswa

Integral Riemann merupakan salah satu materi yang diajarkan pada mata kuliah Kalkulus Integral. Materi ini merupakan materi yang dapat diterapkan pada konsep lain seperti geometri, biologi maupun fisika, yaitu menghitung luasan dibawah kurva atau suatu penampang (Bartle, 2018). Nedaei mengatakan bahwa mahasiswa mengalami kesulitan ketika menyelesaikan soal terkait luas daerah integral dan matematika secara umum (Nedaei, Radmehr, \& Drake, 2021). Bedasarkan wawancara yang dilakukan oleh dosen kepada salah satu mahasiswa diperoleh bahwa materi kalkulus integral merupakan materi yang sulit untuk dipahami. Hal ini dikarenakan sumber belajar yang digunakan masih berbahasa inggris dan sulit dimengerti. Oleh karena itu, penelitian ini bertujuan untuk mengembangkan bahan ajar Kalkulus Integral berbasis pendekatan CT yang valid dan praktis. Bahan ajar ini merupakan bahan ajar utama yang digunakan selama proses perkuliahan berlangsung. Adapun proses pengembangan merupakan kelanjutan 
dari pembuatan bahan ajar yang sudah dilakukan sejak tahun 2019. Selama proses pengembangannya bahan ajar diubah menjadi e-modul menggunakan bahasa indonesia dan berbasis pendekatan computational thinking yang disematkan pada LMS UAD. Bahan ajar dikatakan valid jika memenuhi kriteria minimal valid dari penilaian ahli dan praktis bedasarkan respon positif mahasiswa (Akker, Brenda, Anthony, Nienke, \& Tjeerd, 2013; Hanifah, 2021)

\section{METODE PENELITIAN}

Penelitian ini merupakan penelitian desain riset tipe development studies dengan pendekatan deskriptif kualitatif. Adapun bahan ajar yang dimaksud adalah modul dan LMS Kalkulus Integral berbasis pendekatan CT.

Tahap pengembangan modul dalam penelitian ini meliputi 1) Tahap Preliminary Research yang bertujuan untuk menetapkan dan mendefinisikan syarat-syarat pembelajaran. Tahapan ini dilakukan dengan menganalisa tujuan dalam batasan materi pelajaran yang akan dikembangkan; 2) Tahap Prototyping dilakukan pada tahapan ini adalah merancang prototipe bahan ajar dengan mengintegrasikan modul dengan LMS yang digunakan. Tahapan ini meliputi validasi ahli yang terdiri dari validasi isi dan validitas bahasa. Hasil validasi kemudian digunakan sebagai dasar revisi dan penyempurnaan perangkat pembelajaran. 3) Tahap Assesment berupa uji coba pembelajaran ini dilakukan oleh peneliti saat evaluasi akhir semester. Evaluasi dilakukan dengan memberikan soal terkait dengan konsep yang diajarkan. Pada tahap ini dilakukan pengukuran kemampuan pemecahan masalah mahasiswa (Akker et al., 2013).
Objek penelitian ini adalah bahan ajar berbasis CT. Subjek yang dipilih pada penelitian ini adalah mahasiswa pada mata kuliah Kalkulus Integral tahun ajaran 2020/2021 pada Program Studi Pendidikan Matematika FKIP UAD.

Instrumen penelitian ini meliputi lembar validasi ahli materi dan angket respon mahasiswa terhadap penggunaan bahan ajar selama perkuliahan. Lembar validasi ahli materi digunakan untuk menentukan bahan ajar dikatakan valid sedangkan angket respon mahasiswa digunakan untuk mengetahui kepraktisan bahan ajar yang dikembangkan. Indikator validasi ahli materi yaitu relevansi, keakuratan, kelengkapan sajian, konsep dasar materi, dan kesesuaian sajian dengan tuntutan pembelajaran. Instrumen validasi ahli materi terdiri atas 17 (tujuh belas) butir pernyataan dengan menggunakan skala Likert. Sedangkan indikator angket respon mahasiswa yaitu berupa angket respon penggunaan e-modul kalkulus integral dan angket refleksi pembelajaran. Instrumen angket respon mahasiswa terdiri atas 10 (sepuluh) pernyataan dan angket refleksi pembelajaran terdiri atas 6 butir pernyataan.

Analisis data yang dilakukan meliputi analisis kualitatif deskriptif yang mendeskripsikan validitas dan kepraktisan bahan ajar yan digunakan oleh mahasiswa selama perkuliahan (Yanuarni, Yuanita, \& Maimunah, 2021).

Hasil pengembangan pada penelitian ini menghasilkan bahan ajar yang dintegrasikan dengan LMS dengan kriteria valid dan praktis. Bahan ajar dikatakan valid jika memenuhi kriteria rentang skor (Sr) yang dapat dilihat pada Tabel 1. 
DOI: https://doi.org/10.24127/ajpm.v10i4.4308

Tabel 1. Kriteria valid

\begin{tabular}{cl}
\hline Kriteria Validitas & Tingkat Validitas \\
\hline $\operatorname{Pr}>4,2$ & Sangat valid \\
$3,4 \leq \operatorname{Pr} \leq 4,2$ & Valid \\
$2,6 \leq \operatorname{Pr}<3,4$ & Cukup valid \\
$1,8 \leq \operatorname{Pr}<2,6$ & Kurang praktis \\
$\operatorname{Pr} \leq 1,8$ & Tidak praktis \\
\hline Adaptasi dari (Widiyoko, 2012)
\end{tabular}

Sedangkan kepraktisan dianalisis bedasarkan 10 aspek dengan skala likert skor 1 sampai 5, yang meliputi aspek bahasa, penyajian informasi, kejelasan tujuan pembelajaran, kejelasan materi, motivasi belajar, pemahaman materi, kejelasan huruf dan simbol, penyajian gambar dan video, bahan ajar sebagai sumber belajar, dan keterkaitan materi dengan masalah kontekstual. Adapun pernyataan tersebut merupakan pernyataan favourable dan unfavourable. Pernyataan unfavourable diletakkan pada pernyataan aspek motivasi mahasiswa. Bahan ajar dikatakan praktis jika memenuhi kriteria pada Tabel 2.

Tabel 2. Kriteria Praktis

\begin{tabular}{cl}
\hline Kriteria Kepraktisan & \multicolumn{1}{c}{$\begin{array}{c}\text { Tingkat } \\
\text { Kepraktisan }\end{array}$} \\
\hline $\operatorname{Pr}>4,2$ & Sangat Praktis \\
$3,4 \leq \operatorname{Pr} \leq 4,2$ & Praktis \\
$2,6 \leq \operatorname{Pr}<3,4$ & Cukup Praktis \\
$1,8 \leq \operatorname{Pr}<2,6$ & Kurang praktis \\
$\operatorname{Pr} \leq 1,8$ & Tidak praktis \\
\hline
\end{tabular}

Adaptasi dari (Widiyoko, 2012)

Selanjutnya, data yang diperoleh merupakan data deskriptif kualitatif. Triangulasi yang digunakan adalah triangulasi sumber. Sebanyak lima belas mahasiswa yang mengikuti perkuliahan Kalkulus Integral dipilih sebagai subjek penelitian ini.

Angket diberikan menggunakan google form dengan link https://forms.gle/qBrFovRGpDwHiGco $\underline{9}$ bersamaan dengan lembar keterlaksanaan pembelajaran melalui pendekatan CT. Angket keterlaksanaan pembelajaran menggunakan skala 1 s.d. 5 dengan 1 menyatakan "sangat tidak sesuai" dan 5 menyatakan "sangat sesuai". Instrumen yang digunakan disusun dan divalidasi oleh 1 dosen yang mengampu rumpun analisis pada prodi pendidikan matematika FKIP UAD.

Melalui ketiga aktivitas tersebut, dilakukan sistematik refleksi dan dokumentasi untuk menghasilkan teori atau prinsip desain secara ilmiah. Kegiatan tersebut berfokus pada proses spesifik yaitu kevalidan dan kepraktisan bahan ajar yang dikembangkan.

\section{HASIL DAN PEMBAHASAN}

Hasil pengembangan yang dilakukan dijabarkan sebagai berikut.

1. Tahap Preliminary Research

Pada tahap preliminary research diperoleh fokus utama dalam pengembangan ini adalah bahan ajar kalkulus integral terutama pada materi integral Riemann. Materi tersebut merupakan materi yang penting karena sangat berkaitan dengan konsep-konsep yang akan dipelajari pada mata kuliah analisis lain seperti kalkulus multivariabel dan analisis real (Bartle, 2018).

Penentuan subjek dilakukan dengan memilih mahasiswa secara purposive sampling dan telah tuntas dalam mata kuliah kalkulus diferensial pada semester sebelumnya (semester gasal 2020/2021). Selain itu, mahasiswa berada dalam satu kelas dan diberikan pembelajaran dengan pendekatan CT yang sama.

Mata kuliah kalkulus integral merupakan mata kuliah yang telah banyak mendapatkan beberapa modifikasi desain pembelajaran yang mendukung keaktifan mahasiswa di tiap tahunnya, seperti implementasi lesson 
study pada tahun 2017, impplementasi pendekatan flipped classroom pada tahun 2018, bahkan telah mengimplementasi model pembelajaran Problem Based Learning di tahun 2019 (Setyawan \& Istiandaru, 2019; Setyawan, Sumargiyani, \& Hamzah, 2017). Bedasarkan hasil penelitian tersebut, belum diperoleh desain ideal yang dapat digunakan untuk meningkatkan kemampuan pemecahan masalah mahasiswa. Sehingga diperlukan suatu pendekatan yang mampu mengakomodasi kemampuan pemecahan masalah mahasiswa melalui soal-soal yang diberikan secara terstruktur sehingga mahasiswa dapat melakukan abstraksi dari materi yang diberikan. Hal ini sejalan dengan pendapat bahwa Joseph Agbo, Sunday Oyelere, Adewumi, \& Suhonen (2019) yang berpendapat bahwa penting untuk merancang bahan pembelajaran yang memungkinkan pembelajar yang dalam hal ini mahasiswa untuk mengabstraksi konsep yang berkaitan dengan konteks kehidupan sehari-hari. Oleh karena itu, desain pembelajaran CT menjadi salah satu alternatif yang mampu mengakomodasi mahasiswa untuk mempelajari materi kalkulus integral yang bersifat abstrak sehingga membangun kemampuan pemecahan masalah (Joseph Agbo et al., 2019).

Analisis kurikulum dilakukan peneliti dengan menelaah materi yang disampaikan pada mata kuliah Kalkulus Integral bedasarkan Rencana Pembelajaran Semester yang telah dikembangkan. Mata kuliah Kalkulus Integral merupakan mata kuliah yang diambil pada semester genap, dengan kalkulus diferensial sebagai mata kuliah prasyarat dan kalkulus multivariabel sebagai mata kuliah lanjutan pada semester berikutnya. Mata kuliah ini memiliki beban dua sks bagi mahasiswa prodi pendidikan matematika.

Adapun analisis tugas yang diberikan merupakan tugas terkait konstruksi integral menggunakan deret Riemann. Mahasiswa diminta untuk mengerjakan soal yang diberikan di modul sebagai latihan. Selain itu, analisis tujuan pembelajaran yang diambil adalah mahasiswa dapat menyelesaikan masalah yang berkaitan dengan luas daerah di bawah grafik fungsi yang diketahui.

\section{Tahap Prototyping}

Pada tahap ini dosen medesain bahan ajar dengan mengintegrasikan modul yang digunakan dengan LMS. Mahasiswa dapat mengakses modul dengan cara mengunduh pada link yang telah disediakan. Sedangkan dosen mendesain LMS sebagai bahan evaluasi mahasiswa. Konten yang disediakan pada LMS merupakan evaluasi materi yang diajarkan di modul.

Bedasarkan hasil validasi diperoleh nilai $\mathrm{Sr}=4,76$ dan berada pada kategori valid. Adapun revisi yang dilakukan adalah mengenai konsep yang dibangun menggunakan poligon-poligon luar atau poligon dalam kurva. Ilustrasi bahan ajar yang telah direvisi disajikan pada Gambar 2.

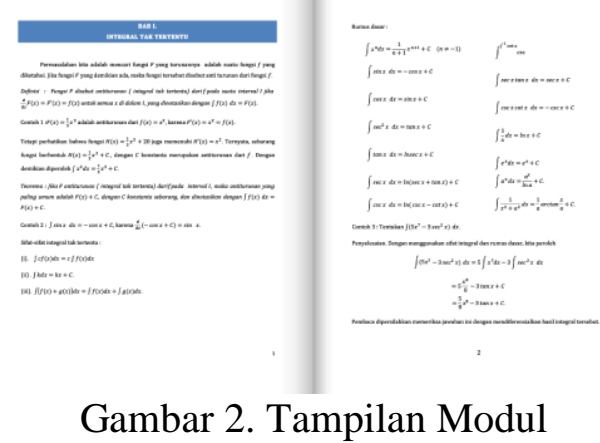

Adapun bahan ajar yang dikembangkan meliputi e-modul yang diintegrasikan pada LMS UAD dengan alamat 
DOI: https://doi.org/10.24127/ajpm.v10i4.4308

https://elearning.uad.ac.id/course/view.p

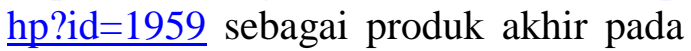
tahap Prototyping. Ilustrasi konten yang dihasilkan pada tahap prototyping disajikan pada Gambar 3.

Integral Tentu dan Volume dibawah kurva

Jawaban Soal Latihan Volume dibawah Kurva

$\sqrt{7}$

UAS

Soal UAS Kalkulus Integral 2021

$\sqrt{7}$

Terbatas Tersedia mulai 24 July 2021, 08:00

PETUNJUK:

1. Berdoalah terlebih dahulu sebelum mengerjakan soal-soal.

2. Kerjakan terlebih dahulu soal yang Saudara anggap paling mudah.

3. Kerjakan setiap soal dengan JUJUR, CERMAT, dan TELITI.

4. Jawaban dikumpulkan di elearning.uad.ac.id

Unggah Jawaban dan isi Kuesioner Kuliah

1. Scan jawaban dengan menggunakan kamera HP atau scanner

2. Unggah jawaban dalam bentuk pdf pada google form yang disediakan

3. Isi kuesioner Respon E-Modul dan Refleksi Pembelajaran

4. Submit

Gambar 3. Integrasi Bahan Ajar Kalkulus Integral di LMS

\section{Tahap Assessment}

Pada tahap assessment, dipilih 15 mahasiswa sebagai subjek penelitian. Pada tahap ini peneliti menguji kepraktisan bahan ajar yang dikembangkan. Adapun respon mahasiswa dijabarkan pada Tabel 3.

Tabel 3. Respon mahasiswa terhadap emodul

\begin{tabular}{clc}
\hline No & Aspek & Sr \\
\hline 1 & Bahasa & 3,93 \\
2 & Penyajian Informasi & 3,67 \\
3 & Kejelasan tujuan & 4,13 \\
& pembelajaran & \\
4 & Kejelasan materi & 4,00 \\
5 & Motivasi belajar & 3,60 \\
6 & Pemahaman Materi & 3,40 \\
7 & Kejelasan huruf dan & 3,93 \\
\hline
\end{tabular}

\begin{tabular}{clc}
\hline No & Aspek & Sr \\
\hline \multirow{2}{*}{8} & $\begin{array}{l}\text { Simbol } \\
\text { Penyajian gambar dan } \\
\text { video }\end{array}$ & 3,26 \\
9 & $\begin{array}{l}\text { Modul sebagai sumber } \\
\text { belajar }\end{array}$ & 4,13 \\
10 & $\begin{array}{l}\text { Keterkaitan materi dengan } \\
\text { masalah kontekstual }\end{array}$ & 3,87 \\
Rata-rata & 3,79 \\
\hline
\end{tabular}

Adapun deskripsi dari masing-masing aspek dijelaskan sebagai berikut.

\subsection{Aspek bahasa}

Pada aspek bahasa diperoleh bahwa sebanyak 20\% mahasiswa menilai bahan ajar dengan kategori cukup, $66,7 \%$ mahasiswa menilai baik, dan $13,3 \%$ mahasiswa menilai 
bahan ajar dengan kategori sangat baik (lihat Gambar 4).

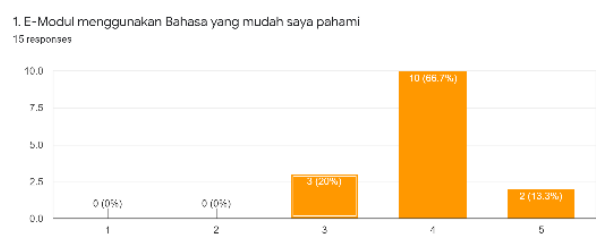

Gambar 4. Respon mahasiswa pada aspek bahasa

3.2 Aspek Penyajian informasi

Pada aspek penyajian informasi sebanyak $13,3 \%$ mahasiswa menilai kurang, 26,7\% mahasiswa menilai cukup, $40 \%$ mahasiswa memilih menilai baik, dan sebanyak $20 \%$ mahasiswa menilai sangat baik. Adapun penyajiannya dapat dilihat pada Gambar 5.

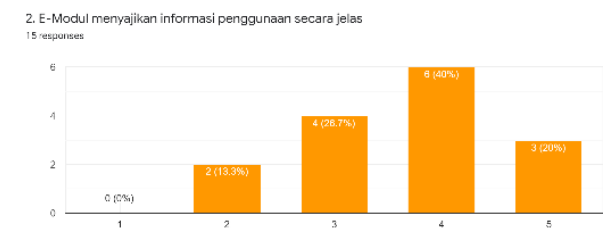

Gambar 5. Respon mahasiswa pada penyajian informasi di bahan ajar

3.3 Aspek kejelasan tujuan pembelajaran

Pada aspek kejelasan tujuan pembelajaran diperoleh sebanyak $13,3 \%$ mahasiswa menilai cukup, $60 \%$ mahasiswa menilai baik, dan 26,7\% mahasiswa menilai sangat baik. Adapun penyajiannya dapat dilihat pada Gambar 6.

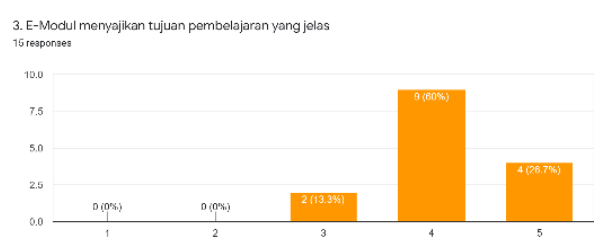

Gambar 6. Respon mahasiswa pada penyajian tujuan pembelajaran
3.4 Aspek kejelasan materi

Pada aspek kejelasan materi sebanyak $13,3 \%$ mahasiswa menilai cukup, $73,3 \%$ mahasiswa menilai baik, dan 13,3\% mahasiswa menilai sangat baik. Adapun penyajiannya dapat dilihat pada Gambar 7.

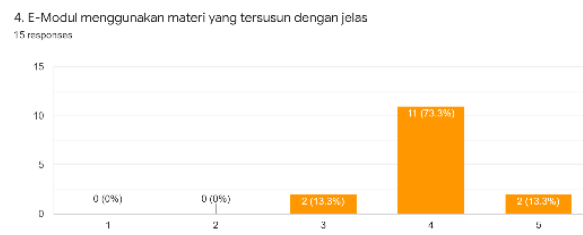

Gambar 7. Respon mahasiswa pada aspek kejelasan materi

3.5 Aspek motivasi belajar

Pada aspek motivasi belajar sebanyak $26,7 \%$ mahasiswa menilai sangat baik, $33,3 \%$ mahasiswa menilai baik, $13,3 \%$ mahasiswa menilai cukup dan 26,7\% mahasiswa menilai kurang. Adapun penyajiannya dapat dilihat pada Gambar 8.

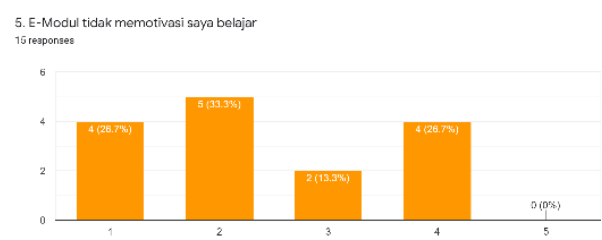

Gambar 8. Respon mahasiswa pada aspek motivasi belajar

3.6 Aspek pemahaman materi

Pada Gambar 9 terkait aspek pemahaman materi sebanyak $6,7 \%$ mahasiswa menilai sangat kurang, $6,7 \%$ mahasiswa menilai kurang, $40 \%$ mahasiswa menilai cukup, $33,3 \%$ mahasiswa menilai baik, dan $13,3 \%$ mahasiswa menilai sangat baik. 
DOI: https://doi.org/10.24127/ajpm.v10i4.4308

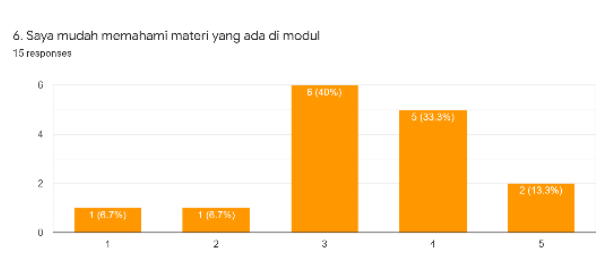

Gambar 9. Respon mahasiswa pada aspek pemahaman materi

3.7 Aspek kejelasan huruf dan simbol Pada aspek kejelasan huruf dan simbol sebanyak $6,7 \%$ mahasiswa menilai kurang, 20\% mahasiswa menilai cukup, $46,7 \%$ mahasiswa menilai baik, dan $26,7 \%$ mahasiswa menilai sangat baik. Adapun penyajiannya dapat dilihat pada Gambar 10.

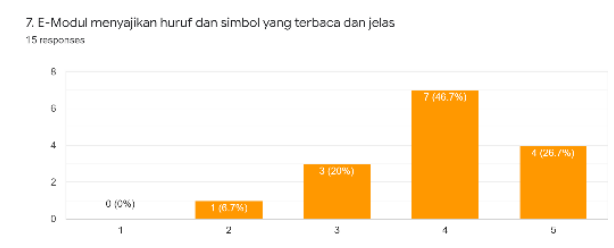

Gambar 10. Respon mahasiswa pada aspek kejelasan huruf dan simbol

3.8 Aspek penyajian gambar dan video

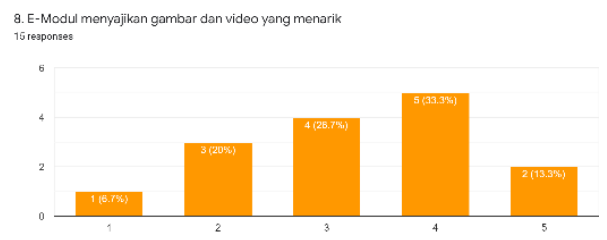

Gambar 11. Respon mahasiswa pada aspek penyajian gambar dan video

Pada aspek penyajian gambar dan video sebanyak $6,7 \%$ mahasiswa menilai sangat kurang, $20 \%$ menilai kurang, 26,7\% mahasiswa menilai cukup, 33,3\% mahasiswa menilai baik, dan 13,3\% mahasiswa menilai sangat baik. Adapun penyajiannya dapat dilihat pada Gambar 11.
3.9 Aspek bahan ajar sebagai sumber belajar

Pada aspek bahan ajar sebagai sumber utama belajar sebanyak 6,7\% mahasiswa menilai kurang, $66,7 \%$ mahasiswa menilai baik, dan $26,7 \%$ mahasiswa menilai sangat baik. Adapun penyajiannya dapat dilihat pada Gambar 12.

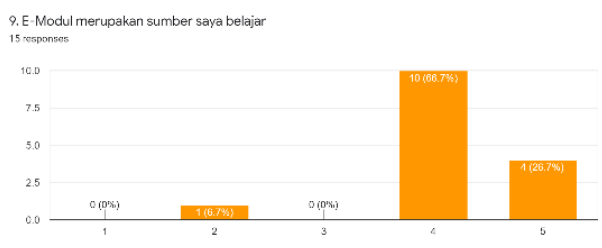

Gambar 12. Respon mahasiswa pada aspek bahan ajar sebagai sumber belajar

3.10 Aspek keterkaitan materi dengan masalah kontekstual

Pada aspek keterkaitan materi dengan masalah kontekstual sebanyak $6,7 \%$ mahasiswa menilai kurang, 20\% mahasiswa menilai cukup, 53,3\% mahasiswa menilai baik, dan $20 \%$ mahasiswa menilai sangat baik. Adapun penyajiannya dapat dilihat pada Gambar 13.

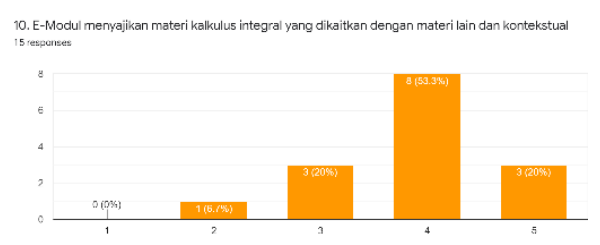

Gambar 13. Respon mahasiswa pada aspek keterkaitan materi dengan masalah kontekstual

Bedasarkan hasil dari aspek kepraktisan melalui respon mahasiswa pada emodul dapat disimpulkan bahan ajar sangat praktis $(\operatorname{Pr}=3,79)$. Adapun catatan yang diperoleh bedasarkan respon mahasiswa diperoleh bahwa skor penyajian gambar dan video mendapatkan skor paling rendah. Sehingga bedasarkan respon tersebut 
gambar dan video pada bahan ajar diperbaiki resolusinya menjadi lebih baik.

Adapun deskripsi dari masing-masing aspek dijelaskan sebagai berikut.

1. Decomposition

Pada Gambar 13, sebanyak 73,3\% mahasiswa memahami konsep yang diberikan dengan pemberian masalah melalui soal yang diberikan di awal pembelajaran.

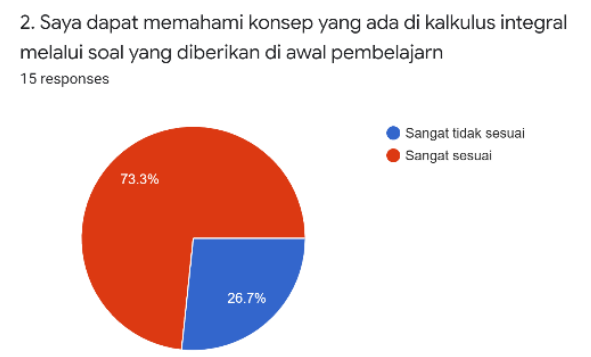

Gambar 13. Respon mahasiswa pada pendekatan CT dengan langkah decomposition

\section{Pattern Recognition}

Pada Gambar 14, sebanyak $46,7 \%$ mahasiswa mengaitkan pengetahuan mahasiswa sebelumnya melalui orientasi yang dilakukan dosen.

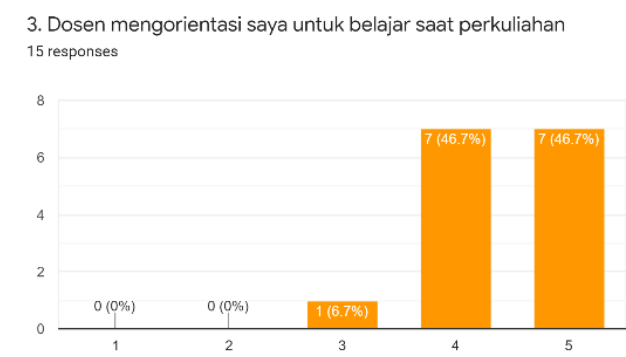

Gambar 14. Respon mahasiswa pada pendekatan CT dengan langkah pattern recognition

\section{Abstraction}

Mahasiswa melakukan abstraksi dari konsep yang diberikan melalui scaffolding yang diberikan oleh guru. Mahasiswa merasa terbantu dengan adanya pembimbingan dari dosen saat menyelesaikan masalah yang diberikan Pada Gambar 15 dapat dilihat bahwa sebanyak $40 \%$ mahasiswa setuju dosen melakukan pembimbingan saat mahasiswa menyelesaikan masalah.

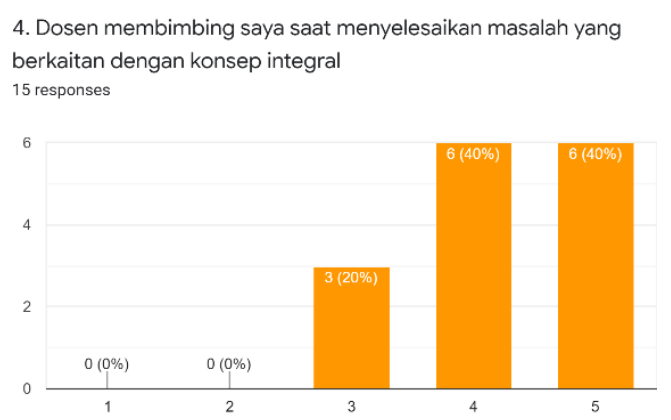

Gambar 15. Respon mahasiswa pada pendekatan CT dengan langkah abstraction

\section{Algoritm}

Pada Gambar 16 mahasiswa merasa mendapatkan kesempatan untuk berdiskusi dan menyampaikan pemikirannya saat perkuliahan (sebanyak 53,3\% mahasiswa setuju dengan pernyataan tersebut)

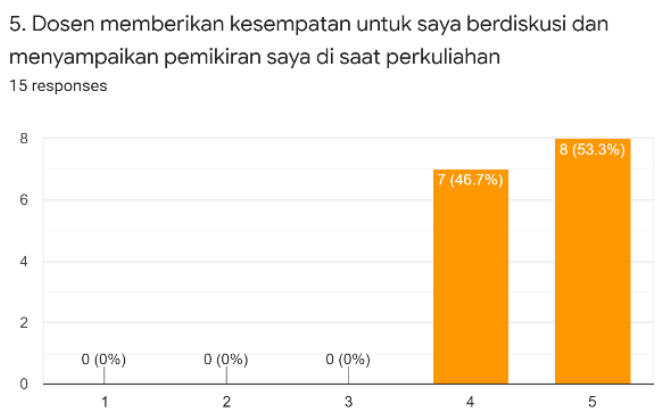

Gambar 16. Respon mahasiswa pada pendekatan CT dengan langkah algoritms 


\section{Debugging}

Pada tahap debugging sebanyak $40 \%$ mahasiswa setuju bahwa dosen memberikan kesempatan untuk mengevaluasi diri melalui tugas yang diberikan di e-learning (Gambar 17).

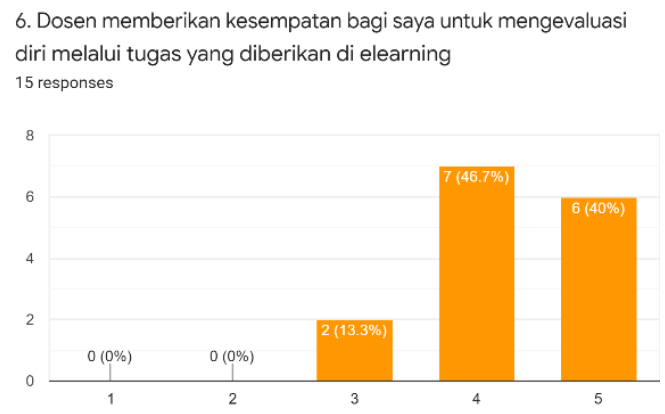

Gambar 17. Respon mahasiswa pada pendekatan CT dengan langkah Debugging

Berdasarkan hasil penelitian tersebut diperoleh bahwa mahasiswa merasakan kebermanfaatan dari penggunaan modul yang diintegrasikan pada e-learning melalui pendekatan CT. Berdasarkan kegiatan ditemukan bahwa pemberian soal dalam bentuk pemecahan masalah besar menjadi permasalahan yang lebih kecil dapat menjadi bagian dari pembelajaran. Hal ini sejalan dengan pendapat Nedaei yang mengatakan bahwa pemberian soal dalam pembelajaran dan evaluasi dapat membantu mahasiswa terutama pada level perguruan tinggi untuk memahami aplikasi dari integral (Nedaei et al., 2021). Hal ini sejalan dengan karakteristik dari pendekatan CT dimana mahasiswa mengaitkan pengetahuan lampau mereka dengan materi yang akan diajarkan. Selain itu, pengembangan bahan ajar yang dilakukan oleh peneliti memberikan kesempatan kepada mahasiswa untuk melakukan abstraksi, berdiskusi, menyampaikan pendapat, dan mengevaluasi secara mandiri selama perkuliahan.

Zapalska, Nowduri, Imbriale, \& Wroblewski (2018) mengkategorikan proses berpikir kompleks atau berpikir tingkat tinggi kedalam empat kelompok yaitu pemecahan masalah (problem solving), pengambilan keputusan (decision making), berpikir kritis (critical thinking), dan berpikir kreatif (creative thinking). Kemampuan pemecahan masalah dengan setting pendekatan CT merupakan salah satu proses berpikir tingkat tinggi. Hal ini dikarenakan mahasiswa dibiasakan untuk melakukan abstraksi dan evaluasi (C5) saat menyelesaikan masalah.

Selain itu, diketahui bahwa saat mahasiswa memecahkan suatu permasalahan tentu diperlukan data-data agar dapat dibuat keputusan yang logis, dan untuk membuat suatu keputusan yang tepat, diperlukan kemampuan abstraksi dan evaluasi yang baik. Hal ini ditunjukkan pada komentar mahasiswa yaitu melalui bahan ajar yang telah dikembangkan disimpulkan bahwa bahan ajar dapat memfasilitasi dan menjelaskan materi secara urut dan terperinci.

>>Bedasarkan data yang diperoleh penelitian ini memberikan gambaran mengenai pengembangan bahan ajar pada mata kuliah kalkulus integral yang valid dan praktis. Adapun bahan ajar dapat diakses kapanpun dan dimanapun oleh mahasiswa. Namun penelitian ini terbatas pada penggunaan bahan ajar yang diintegrasikan dengan LMS Universitas Ahmad Dahlan. Oleh karena itu bahan ajar ini belum tentu sesuai jika diimplementasikan pada situasi dan lingkungan di luar Universitas Ahmad Dahlan. Mahasiswa UAD dapat mengakses bahan ajar jika mereka terdaftar sebagai mahasiswa yang mengikuti perkuliahan Kalkulus 
Integral di LMS. Adapun dampak yang diperoleh mahasiswa terhadap penelitian ini adalah pengembangan bahan ajar sebagai sumber ajar primer yang sesuai dengan kebutuhan mahasiswa di masa pandemi.

\section{KESIMPULAN DAN SARAN}

Bedasarkan data dan pembahasan tersebut dapat disimpulkan bahwa pengembangan bahan ajar mata kuliah Kalkulus Integral berada pada kategori sangat valid $(\mathrm{Sr}=4,76)$. Bahan ajar berada pada kategori praktis diperoleh dari respon mahasiswa saat menggunakan e-modul $(\operatorname{Pr}=3,79)$.

Selain itu, melalui refleksi pembelajaran berbasis CT diperoleh sebanyak 73,3\% mahasiswa memahami konsep yang diberikan dengan pemberian masalah melalui soal yang diberikan di awal pembelajaran, 46,7\% mahasiswa mengaitkan pengetahuan mahasiswa sebelumnya melalui orientasi yang dilakukan dosen, $40 \%$ mahasiswa setuju dosen melakukan pembimbingan saat mahasiswa menyelesaikan masalah, 53,3\% mahasiswa mendapatkan kesempatan untuk berdiskusi dan menyampaikan pemikirannya saat perkuliahan, dan $40 \%$ mahasiswa setuju bahwa dosen memberikan kesempatan untuk mengevaluasi diri melalui tugas yang diberikan di e-learning.

Saran untuk penelitian berikutnya adalah dapat melanjutkan penelitian eksperimen untuk mengukur pengaruh penggunaan bahan ajar ini adalah untuk meningkatkan kemampuan pemecahan masalah mahasiswa pendidikan matematika.

\section{UCAPAN TERIMA KASIH}

Terima kasih kepada Bidang Riset dan Inovasi Lembaga Penelitian dan Pengabdian kepada Masyarakat
(LPPM) UAD, Prodi Pendidikan Matematika Fakultas Keguruan dan Ilmu Pendidikan UAD, Mahasiswa, dan seluruh pihak yang telah mendukung dan terlibat dalam penelitian ini.

\section{DAFTAR PUSTAKA}

Akker, J. van den, Brenda, B., Anthony, E. K., Nienke, N., \& Tjeerd, P. (2013). Educational Design Research. In N. Nieveen \& $\mathrm{T}$. Plomp (Eds.), Educational Design Research, Part A: An introduction (Part A, p. 72). https://doi.org/10.1007/978-14614-3185-5_11

Angeli, C., \& Giannakos, M. (2020, April 1). Computational thinking education: Issues and challenges. Computers in Human Behavior, Vol. 105, p. 106185. https://doi.org/10.1016/j.chb.2019. 106185

Bartle, R. G. (2018). Return to the Riemann Integral. Https://Doi.Org/10.1080/00029890 .1996.12004798, 103(8), 625-632. https://doi.org/10.1080/00029890.1 996.12004798

Domingo, M. G., \& Garganté, A. B. (2016). Exploring the use of educational technology in primary education: Teachers' perception of mobile technology learning impacts and applications' use in the classroom. Computers in Human Behavior, 56, 21-28. https://doi.org/10.1016/j.chb.2015. 11.023

Hanifah, H. (2021). Practicality test of student worksheet (SWS) based on: Action, Process, Object, Schema (APOS model) assisted on Geogebra the subject of Riemann sum. Journal of Physics: Conference Series, 1731(1), 012035. 
DOI: https://doi.org/10.24127/ajpm.v10i4.4308

https://doi.org/10.1088/17426596/1731/1/012035

Jacinto, H., \& Carreira, S. (2021). Digital Tools and Paper-AndPencil In Solving-and-Expressing: How Technology Expands A Student's Conceptual Model of A Covariation Problem. Journal on Mathematics Education, 12(1), 113-132.

https://doi.org/10.22342/JME.12.1. 12940.113-132

Joseph Agbo, F., Sunday Oyelere, S., Adewumi, S., \& Suhonen, J. (2019). A Systematic Review of Computational Thinking Approach for Programming Education in Higher Education Institutions. Proceedings of the 19th Koli Calling International Conference on Computing Education Research, 10, 1-10. https://doi.org/10.1145/3364510

Nedaei, M., Radmehr, F., \& Drake, M. (2021). Exploring undergraduate engineering students' mathematical problem-posing: the case of integral-area relationships in integral calculus. Mathematical Thinking and Learning. https://doi.org/10.1080/10986065.2 020.1858516

Pischetola, M., de Miranda, L. V. T., \& Albuquerque, P. (2021). The invisible made visible through technologies' agency: a sociomaterial inquiry on emergency remote teaching in higher education. Https://Doi.Org/10.1080/17439884 .2021.1936547, 46(4), 390-403. https://doi.org/10.1080/17439884.2 021.1936547

Setyawan, F., \& Istiandaru, A. (2019). Implementasi Self Regulated Flipped Classroom pada Mata Kuliah Kalkulus. Journal of
Medives: Journal of Mathematics Education IKIP Veteran Semarang, 3(1), 119-124. https://doi.org/10.31331/medivesve teran.v3i1.699

Setyawan, F., Prasetyo, P. W., \& Nurnugroho, B. A. (2020). Developing complex analysis textbook to enhance students critical thinking. JRAMathEdu (Journal of Research and Advances in Mathematics Education), 5(1), 26-37. https://doi.org/10.23917/jramathed u.v5i1.8741

Setyawan, F., Sumargiyani, S., \& Hamzah, R. (2017). LESSON STUDY : GALLERY WALK TO SUPPORT STUDENTS. The First AD INTERCOMME. Yogyakarta: Universitas Ahmad Dahlan.

Son, A. L., Darhim, D., \& Fatimah, S. (2020). Students' Mathematical Problem-Solving Ability Based on Teaching Models Intervention and Cognitive Style. Journal on Mathematics Education, 11(2), 209-222.

https://doi.org/10.22342/JME.11.2. 10744.209-222

Widiyoko, S. E. P. (2012). Teknik Penyusunan Instrumen Penelitian (Delapan) (8th ed.). Yogyakarta: Pustaka Pelajar.

Yadav, A., Zhou, N., Mayfield, C., Hambrusch, S., \& Korb, J. T. (2011). Introducing computational thinking in education courses. SIGCSE'11 - Proceedings of the 42nd ACM Technical Symposium on Computer Science Education, 465-470.

https://doi.org/10.1145/1953163.19 53297

Yanuarni, R., Yuanita, P., \& Maimunah, M. (2021). Pengembangan Perangkat Pembelajaran Model 
DOI: https://doi.org/10.24127/ajpm.v10i4.4308

Problem Based Learning Terintegrasi Keterampilan Abad 21. AKSIOMA: Jurnal Program Studi Pendidikan Matematika, 10(2), 536-549. https://doi.org/10.24127/AJPM.V1 0I2.3331

Zapalska, A. M., Nowduri, S., Imbriale, P., \& Wroblewski, B. (2018). A Framework for Critical Thinking Skills Development Across Business Curriculum Using the 21 st Century Bloom 's Taxonomy Keywords. Interdisciplinary Education and Psychology, 2(1), $1-14$. 